\title{
SPACE REACTOR FUEL ELEMENT TESTING IN UPGRADED TREAT*
}

\author{
Michael Todosow, Paul Bezler, Hans Ludewig, and Walter Y. Kato \\ Brookhaven National Laboratory \\ Upton, NY 11973 \\ (516) $282-2445$
}

\begin{abstract}
The testing of cardidate fuel elements at prototypic operating conditions with respect to temperature, power density, hydrogen coolant flow rate, etc., is a crucial component in the development and qualification of nuclear rocket engines based on the Particle Bed Reactor (PBR), NERVA-derivative, and other concepts. Such testing may be performed at existing reactors, or at new facilities. A scoping study has been performed to assess the feasibility of testing PBR based fuel elements at the TREAT reactor. Initial results suggest that full-scale PBR elements could be tested at an average energy deposition of $\sim 60-80 \mathrm{MW}-\mathrm{s} / \mathrm{L}$ in the current TREAT reactor. If the TREAT reactor was upgraded to include fuel elements with a higher temperature limit, average energy deposition of $\sim 100 \mathrm{MW} / \mathrm{L}$ may be achievable.
\end{abstract}

\section{INTRODUCTION}

A critical component in the development of nuclear rocket propulsion engines for Space Exploration Initiative (SEI) missions is a highly robust fuel element which can operate at high temperatures in a bydrogen environment. Fuel elements require extensive in-pile and out-of-pile testing at prototypic operating temperatures, power distribution, power density, gaseous coolant flow rate, pressure, and operating time to determine operating capability and safety margins. The design, construction, and operation of a specific multiple fuel element testing reactor for space reac.or fuel elements would require considerable time and resources in today's environment. Rapid and early testing of single fuel elements whether they be Particle Bed Reactor (PBR) or NERVA based fuel elements is essential to determine the optimum approach for the design of SEI mission nuclear rockct engines. It is proposed to modify existing Department of Energy reactors such as TREAT which is operated by the Argonne National Laboratory at the Idaho National Engineering Laboratory (INEL) site to conduct full scale, single element tests of PBR or NERVA-derivative fuel at close to prototypic operating conditions and environments, as well as construct new facilities at other possible sites.

TREAT (Freund) is a graphite moderated thermal reactor which has been operating since about 1960 . There have been numerous transient fuel element tests conducted at the facility for the Atomic Energy Commission and Department of Energy fast reactor programs. It has a core size of $1.92 \times 1.92$ meters in cross sectional arca and a height of 1.22 meters as shown in Figures 1 and 2 . It has fuel elements of $0.10 \times 0.10 \times 1.22$ meters in height consisting of highly enriched $\mathrm{UO}_{2}$ mixed with graphite encased in zircaloy cladding. Its transient capabilities are:

$\begin{array}{ll}\text { Integrated Power: } & 2500 \mathrm{MW}-\mathrm{s} \\ \text { Peak Power: } & 19000 \mathrm{MW} \\ \text { Minimum Period: } & 0.023 \mathrm{~s} \\ \text { Maximum Del K/K } & 4.5 \% \\ \text { Max. Fuel Clad Temp: } & 873 \mathrm{~K}\end{array}$

Experimental cavities are produced by removing one or more $0.10 \times 0.10$ meters fuel elements.

\footnotetext{
\#Research carried out under the auspices of the U.S. Department pf Energy, Contract No. DE-ACO2$76 a 100016$. 


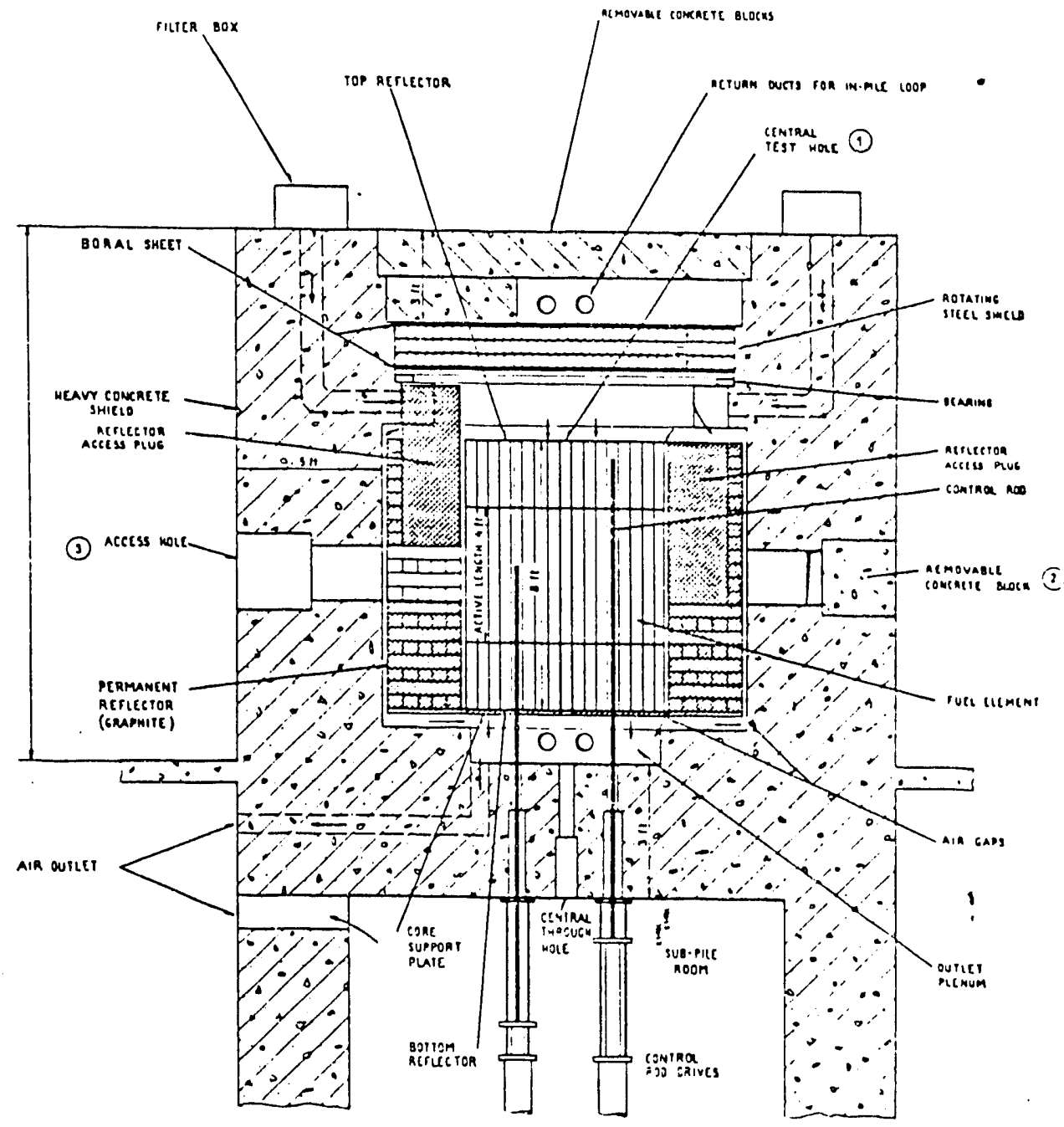

FIGURE 1. Treat Vertical Cross Section. 


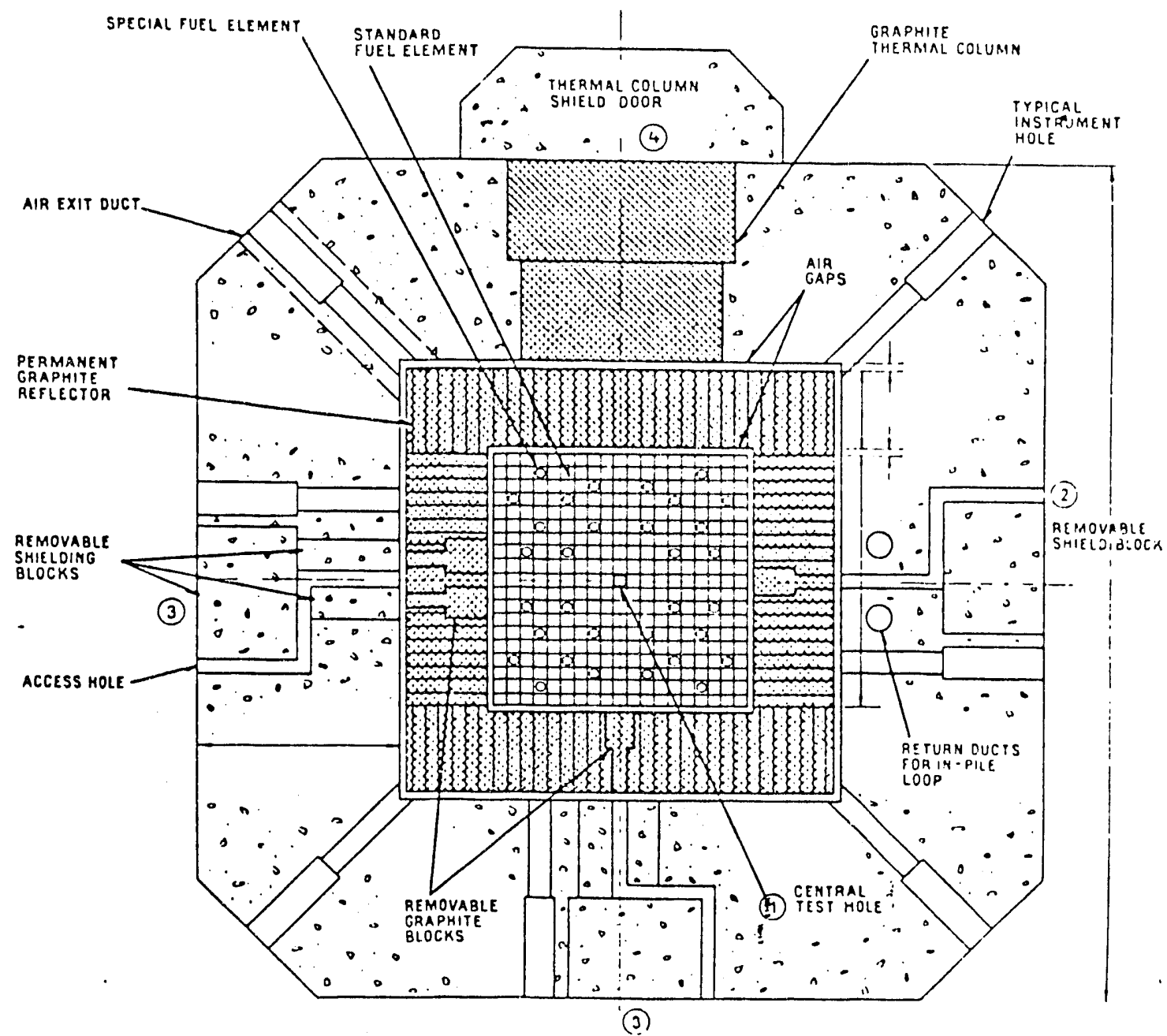

IORIZONTAL SECTION TREAT

FIGURE 2. Treat Horizontal Cross Section. 
Preliminary studies have been carried out for testing PBR type fuel elements in the TREAT reactor. The concept is to carry out tests of full sized PBR fuel elements which would be operated in a hydrogen coolant blowdown mode at as high a power density and for the longest time possible within the capability of TREAT. This test would simulate prototypic temperatures, temperature distributions, pressures, and prototypic power densities and coolant flow rates for space nuclear propulsion systems. In addition nuid structure interaction would be investigated to determine regions of stability. This flow stability phenomenon cannot be investigated rigorously in any other proposed non-nuclear test. The demonstration of mechanical stability of a fuel element while operating at full power is a crucial requirement prior to operation in a reactor.

Preliminary designs of experimental packages, which include a PBR fuel element and the appropriate coolant ducting loop have been carried out. An example of such a layout is shown on Figure 3. Coolant is ducted into the experiment in a coaxial space surrounding the exhaust duct and fuel element. It flows radially through the fuel element and then out the central duct. Analyses of this configuration in the TREAT reactor using the MCNP, (Briesmeister) Monte Carlo reactor physics code, indicate that it would be possible to deposit $\sim(0)-\$ 0$ MW-s/L in the test element. This energy deposition implies that it would be possible to operate a full-scale element at power densities of $6-8 \mathrm{MW} / \mathrm{L}$ for about $10 \mathrm{~s}$, or $15 \mathrm{MW} / \mathrm{L}$ for approximately $4-5 \mathrm{~s}$ with prototypic hydrogen flow conditions. About ten years ago inconel clad fuel elements were fabricated for an Upgraded Treat (UT) facility. If inconel clad fuel elements replaced a significant fraction of the central core region (which would allow the fuel clad temperatures to reach about $1123 \mathrm{~K}$ ), it is estimated that power densities of about $100 \mathrm{M} / \mathrm{W}$ $\mathrm{s} / \mathrm{L}$ might be attained in a PBR type fuel element. This means that power densities of $10 \mathrm{MW} / \mathrm{L}$ for $10 \mathrm{~s}$ or $20 \mathrm{MW} / \mathrm{L}$ for $5 \mathrm{~s}$ could be attained in the PBR fuel element with typical hydrogen coolant flow rates.

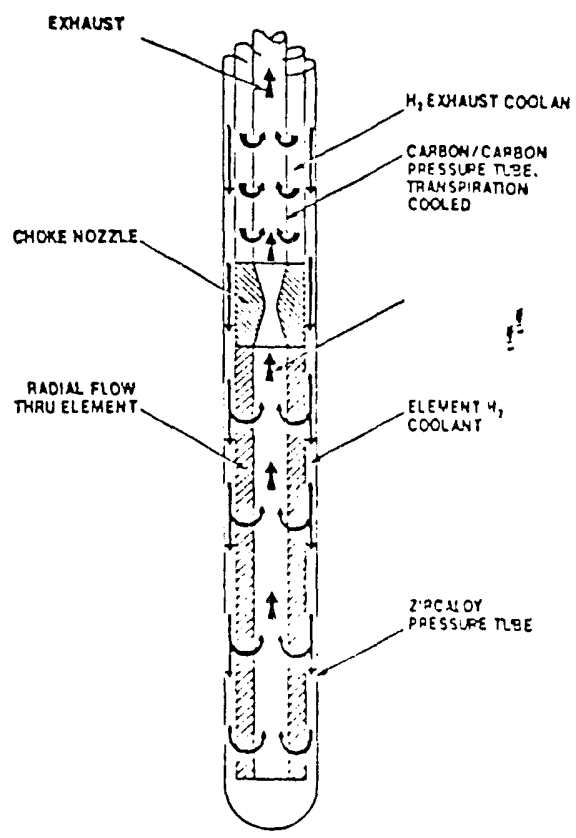

FIGURE 3. PBR Test Loop for Treat. 
The safety considerations of the TREAT facility require that the experimental package does not damage the facility under any conceivable accident scenario. This requirement implies that the loop design include at least the following constraints: (1) All piping containing hydrogen be double walled, with an inert atmosphere in the co-axial volume; (2) Catch tanks for the hydrogen should be shielded in case a failure of a test element results in fuel being exhausted into the tank; (3) The experimental package be enclosed in an evacuated volume in order to thermally isolate it from the reactor; and (4) A carbon/carbon liner be included along the inner wall of the experimental capsule. This liner would protect the pressure vessel wall from hot fuel in the event of a cold frit failure.

Since all the operating conditions cannot be simulated in a single test, it is proposed that a combination of tesis would be required. These tests fall into two broad categories. First, those which operate at low power density and long durations. Second, those operating at high power density and relatively short duration.

If a decision is made to use the TREAT facility, the results of these proposed tests on the UPGRADED TREAT will produce data in a timely manner for confirming the feasibility of PBR fuel elements for high performance nuclear rocket engines. The data could also be used in safety analyses for a fuel element testing reactor or a ground test nuclear rocket engine.

\title{
Acknowledgments
}

Research carrief out under the auspices of the U.S. Department of Energy, Contract No. DE-ACO2$76 \mathrm{CH} 00016$.

\section{References}

Freund, G. A., et al., "Design Summary Report on the Transient Reactor Test Facility (TREAT)," ANL. (NO)3-4, Argonne National Laboratory, Feb. 1960.

Briesmeister, J. F., Editor, "MCNP - A General Monte Carlo Code For Neutron and Photon Transport," LA. 7396-M, Los Alamos National Laboratory, Sept. 1986.

\section{DISCLAIMER}

\begin{abstract}
This report was prepared as an account of work sponsored by an agency of the United States Government. Neither the United States Government nor any agency thereof, nor any of their employees, makes any warranty, express or implied, or assumes any legal liability or responsibility for the accuracy, completeness, or usefulness of any information, apparatus, product, or process disclosed, or represents that its use would not infringe privately owned rights. Reference herein to any specific commercial product, process, or service by trade name, trademark, manufacturer, or otherwise does not necessarily constitute or imply its endorsement, recommendation, or favoring by the United States Government or any agency thereof. The views and opinions of authors expressed herein do not necessarily state or reflect those of the United States Government or any agency thereof.
\end{abstract}

